\title{
Anti-Diabetic Potential Assessment of Aqueous and Ethanol Extracts of Arrow Poison (Strophanthus hispidus) Plant Stem Bark in Wistar Male Rats \\ 1'OSIBEMHE, M; ${ }^{1}$ IBRAHIM, M; ${ }^{2}$ ONOAGBE, IO

\author{
${ }^{l}$ Department of Biochemistry and Molecular Biology, Faculty of Life Science, Federal University Dutsin-Ma, Katsina State, Nigeria, \\ *Corresponding Author Email: mosibemhe@fudutsinma.edu.ng,Tel:+2348063260886. \\ ${ }^{2}$ Department of Biochemistry, Faculty of Life Sciences, University of Benin, Benin-City, Edo State, Nigeria
}

\begin{abstract}
Diabetes mellitus is a chronic disease, for which there is no known cure except in some specific situation. The available orthodox drugs used for its management are having disadvantages. The aim of this study is to evaluate the anti-diabetic potential of aqueous and ethanol extracts of Strophanthus hispidus (SH) stem bark in Wistar male rats. Diabetes mellitus was induced by intraperitoneal injection of streptozotocin $(55 \mathrm{mg} / \mathrm{kg})$. Blood glucose concentrations, serum $\alpha$-amylase and lipid profile of normal and diabetic rats were monitored for 12 weeks. The rats were treated with $250 \mathrm{mg} / \mathrm{kg}$ of aqueous and ethanol extracts of Strophanthus hispidus respectively. Dose-response study was also carried out. The results revealed significant $(\mathrm{P}<0.05)$ progressive decrease in fasting blood glucose concentration on the $2^{\text {nd }}-12^{\text {th }}$ weeks and $4^{\text {th }}-12^{\text {th }}$ weeks in normal and diabetic-treated rats respectively. Total cholesterol, LDL and TG levels were lowered significantly $(\mathrm{P}<0.05)$ by the extracts in normal and diabetic treated rats, whereas HDL levels $(17.6 \pm 0.50 \mathrm{mg} / \mathrm{dl})$ (aqueous) and $(21.4 \pm 1.28 \mathrm{mg} / \mathrm{dl})$ (ethanol) were elevated in diabetic treated rats. The activity of serum $\alpha$-amylase was also elevated by the extract in diabetic treated rats. These findings indicated that SH showed hypoglycemic, anti-hyperlipidemic and anti-diabetic activities. These findings may be connected with the presence and amount of phytochemicals in the plant.
\end{abstract}

\section{DOI: https://dx.doi.org/10.4314/jasem.v23i4.4}

Copyright: Copyright (C) 2019 Osibemhe et al. This is an open access article distributed under the Creative Commons Attribution License (CCL), which permits unrestricted use, distribution, and reproduction in any medium, provided the original work is properly cited.

Dates: Received: 26 January 2019; Revised: 29 March 2019; Accepted 13 April 2019

Keywords: Anti-hyperlipidemic; diabetes; gavage; hypoglycemic; phytochemicals

Diabetes mellitus is a group of metabolic disorders of carbohydrate metabolism in which glucose is underutilized, producing hyperglycemia (Tietz 2008). The increasing global prevalence of diabetes mellitus have led to the disease being described as "one of the main threats to human health in the twenty-first century" (Tietz, 2008). The disease is recognized as an important cause of premature death and disability (WHO 2016). It is one of four priority of noncommunicable diseases (NCDs) targeted by world leaders in the 2011 Political Declaration on the Prevention and Control of NCDs (WHO 2016). To reduce avoidable mortality from diabetes and improve outcomes, access to affordable treatment is critical. Lack of access to insulin in many countries and communities remains a critical impediment to successful treatment efforts. Inadequate access to oral hypoglycemic medication, and medication to control blood pressure and lipids, is also a barrier (WHO 2016). These impediments and a host of others may be the reason for the resurgence of interest in traditional methods of combating the disease. Strophanthushispidus is one of the plants used by the African natives for the management of diabetes.
Preliminary studies on this plant have revealed the presence of important bioactive compounds such as flavonoids, alkaloids, tannins, etc (Osibemhe\&Onoagbe 2015) with glucose lowering potential. This work is, therefore; aimed at determining the anti-diabetic potential of aqueous and ethanol extracts of Strophanthus hispidus (SH) stem bark in Wistar male rats.

\section{MATERIALS AND METHODS}

Animals: Male rats (Wistar strain) obtained from the Department of Anatomy, University of Benin, Benin City, Nigeria were used for this study. The rats (adults, weighing between 220-277 g) were maintained under standard animal house condition and were allowed free access to food (pelletized growers mash produced by Premier Feed Mills Co. Ltd) and water for two weeks to acclimatize to the new environment. All animals were handled with proper care according to the internationally accepted practices for use and care of laboratory animals as contained in US guidelines (NIH, 1992).

Medicinal Plant: The stems of S. hispidus were

*Corresponding Author Email: mosibemhe@fudutsinma.edu.ng, Tel:+2348063260886. 
purchased from Ajagun Market, Ogbomosho, Oyo State, Nigeria. They were identified in the Herbarium Unit of the Department of Botany, University of Benin, Benin City, Nigeria.

Preparation and Extraction of Plant Material:Preparation and extraction of the plant material was carried out according to the method described by Osibemhe and Onoagbe (2015). The stems of S. hispidus were thoroughly washed with clean water and the barks were peeled off by incision. They were then dried under shade for two weeks and then pulverized into fine poder with the aid of a mechanical pulverizer. Measured quantities of the powdered simple were extracted separately in aqueous and $99 \%$ etanol for $72 \mathrm{hrs}$ followed by periodic stirring and they were kept in a refrigerator to avoid any microbial growth. The extracts were filtered using cheese-cloth and the filtrate re-filtered using Whatman No. $42(125 \mathrm{~mm})$ filter paper. The filtrates collected were lyophilized using a freeze-dryer and stored in an air tight container for further analysis.

Chemical and Reagents:All reagents and chemicals used in this study were of analytical grade. Lipid profile and pancreatic function parameters were analyzed using diagnostic kits.

Dose-Response Determination:A total of 45 male rats were used in the experiment. The rats were randomly distributed into 9 groups of five rats each. Four groups were administered orally with the aid of gavage daily doses of $100,250,500$ and $750 \mathrm{mg} / \mathrm{kg}$ body weight of aqueous extract respectively while another four groups received the respective doses of ethanol extract. The control group was administered distilled water. Blood glucose concentration was analyzed on the fourteenth day after overnight fast of the animals using glucometer.

Hypoglycemic and Anti-Diabetic Studies: A total of 30 male rats were used in this experiment. The rats were randomly distributed into six (6) groups of five rats each and were kept in standard cages. Groups 1 and 4 served as normal and diabetic control respectively and received distilled water. Groups 2 and 3 were normal rats and were treated with $250 \mathrm{mg} / \mathrm{kg}$ of aqueous and ethanol extracts of Strophanthus hispidus respectively, whereas groups 5 and 6 were diabetic rats and received the respective dose of the extracts. All administrations were carried out orally using gavage on a daily basis for a period of 12 weeks. Fasting blood glucose analysis and measurement of body weight were carried out at intervals of 2 weeks. At the end of the 12 weeks of extracts administration, the animals were sacrificed and blood was collected for lipid profile and pancreatic function analyses according to the methods described in their respective kits (Randox Laboratories United Kingdom and Teco diagnostic kits respectively).

Determination of Blood Glucose:The analysis was carried out using One Touch ® Glucometer (Lifescan, Inc. 1995 Milpas, California, U.S.A) with blood obtained from the tail of the rats using a syringe to prick the tip after massaging.

Streptozotocin Injection:Diabetes was induced by intraperitoneal injection of $55 \mathrm{mg} / \mathrm{kg} \mathrm{b.w}$. of streptozotocin (STZ) (Sigma St. Louis, MO, U.S.A) reconstituted in normal saline after a 12 hour fast. Control animals received saline only. Seven days post administration of STZ, diabetes was confirmed in STZ treated rats with a fasting blood glucose concentration $\geq 300 \mathrm{mg} / \mathrm{dl}$.

Blood Collection:Blood samples were collected into plain containers through the abdominal aorta from the rats under chloroform anaesthesia using a $5 \mathrm{ml}$ syringe. The blood sample was centrifuged at $3000 \mathrm{rpm}$ for 15 mins. After centrifugation, the sera were aspirated into clean plain sample tubes for the analyses of lipid profile and pancreatic function parameters.

Statistical Analysis:Data are presented as mean \pm S.E.M of five independent determinations. One-Way Analysis of Variance (ANOVA) was used in comparing the means using statistical package for Social Sciences (SPSS) version 16.0, followed by Duncan Post Hoc Multiple Comparisons. Values lower than 0.05 were taken as statistically significant.

\section{RESULTS AND DISCUSSION}

Dose-Response Study: Dose response relation is important in determining pharmacological efficacy of drug substances including herbal preparations. It is also important in therapeutic decision making and for the development of monograph for plants with medicinal values. It is important with respect to toxicology. This study examined the response of varying dose concentrations of extracts of $\mathrm{SH}$ on glucose reduction. The results for a 14 days doseresponse effects of aqueous and ethanol extracts of $S$. hispiduson glucose concentration are presented in tables 1 and 2 respectively. Aqueous extract at the doses of 100, 250, 500, and $750 \mathrm{mg} / \mathrm{kg}$ bw significantly $(\mathrm{p}<0.05)$ reduced glucose concentration on day 14 (Table 1) when compared with control. However, ethanol extract significantly $(\mathrm{p}<0.05)$ lowered blood glucose concentration at the doses of 250 and $750 \mathrm{mg} / \mathrm{kg}$ bw (Table 2). 
Table 1: Dose response effect of aqueous extract of S. hispidus stem bark on blood glucose concentration $(\mathrm{mg} / \mathrm{dl})$

\begin{tabular}{ll}
\hline Group & Day 14 $(\mathbf{m g} / \mathbf{d l})$ \\
\hline Control & $87.20 \pm 1.88^{\mathrm{a}}$ \\
$100 \mathrm{mg} / \mathrm{kg}$ & $80.00 \pm 1.51^{\mathrm{b}}$ \\
$250 \mathrm{mg} / \mathrm{kg}$ & $69.20 \pm 2.08^{\mathrm{cd}}$ \\
$500 \mathrm{mg} / \mathrm{kg}$ & $73.80 \pm 1.59^{\mathrm{c}}$ \\
$750 \mathrm{mg} / \mathrm{kg}$ & $67.00 \pm 2.37^{\mathrm{d}}$ \\
\hline
\end{tabular}

Value are expressed as blood glucose concentration $(\mathrm{mg} / \mathrm{dl})$ and values are means $\pm S E M(n=5)$. Values in the same column with different superscript alphabet are significant $(P<0.05)$ from control.

Both extracts had greater fasting blood glucose lowering effect at 250 and $750 \mathrm{mg} / \mathrm{kg}$ (Tables 1 and 2). However, $250 \mathrm{mg} / \mathrm{kg}$ body weight was used for the diabetic studies for economic reason. The greater glucose reduction exhibited by the extracts at 250 $\mathrm{mg} / \mathrm{kg}$ body weight is an indication of non-monotonic response. Von et al. (1997) have reported the possibility of a low dose to cause greater impact than a high dose for a specific response.
Gupta (2000) has also reported the possibility of similar effect. At 250 and $750 \mathrm{mg} / \mathrm{kg}$ which showed greater glucose lowering response, ethanol extract had lower glucose concentration than aqueous extract. This may not be unconnected with the presence of higher concentration of bioactive compounds (flavonoid and tannins) with glucose lowering potentials in the extract (Tapaset al., 2008; Osibemhe and Onoagbe, 2015).

Table 2:Dose response effect of ethanol extract of $S$. hispidus stem bark on blood glucose concentration $(\mathrm{mg} / \mathrm{dl})$

\begin{tabular}{ll}
\hline Group & Day 14 (mg/dl) \\
\hline Control & $88.40 \pm 2.48^{\mathrm{a}}$ \\
$100 \mathrm{mg} / \mathrm{kg}$ & $83.40 \pm 1.21^{\mathrm{a}}$ \\
$250 \mathrm{mg} / \mathrm{kg}$ & $68.80 \pm 1.39^{\mathrm{b}}$ \\
$500 \mathrm{mg} / \mathrm{kg}$ & $83.60 \pm 1.40^{\mathrm{a}}$ \\
$750 \mathrm{mg} / \mathrm{kg}$ & $67.80 \pm 1.24^{\mathrm{b}}$
\end{tabular}

Value are expressed as blood glucose concentration $(\mathrm{mg} / \mathrm{dl})$ and values are means \pm SEM $(n=5)$. Values in the same column with different superscript alphabet are significant $(\mathrm{P}<0.05)$ from control.

TABLE 2:Mean blood glucose concentrations ( $\mathrm{mg} / \mathrm{dl}$ ) of normal and streptozotocin induced diabetic rats treated with $250 \mathrm{mg} / \mathrm{kg}$ bw of aqueous and ethanol extracts of Strophanthushispidusstem bark for 12 weeks

\begin{tabular}{|c|c|c|c|c|c|c|c|c|}
\hline & & & & Blood glucose & oncentration (mg & & & \\
\hline Treatment & Basal & Day one & Week 2 & Week 4 & Week 6 & Week 8 & Week 10 & Week 12 \\
\hline N/Control & $82.80 \pm 1.93^{\mathrm{a}}$ & $82.8 \pm 1.59^{a}$ & $84 . .8 \pm 2.43^{\mathrm{a}}$ & $81.60 \pm 1.60^{\mathrm{a}}$ & $83.2 \pm 1.77^{\mathrm{a}}$ & $83.8 \pm 1.59^{\mathrm{a}}$ & $82.4 \pm 1.69^{a}$ & $81.8 \pm 1.07^{\mathrm{a}}$ \\
\hline $\mathrm{N}+$ Aqueous & $81.20 \pm 3.71^{\mathrm{a}}$ & $80.0 \pm 2.59^{\mathrm{a}}$ & $71.0 \pm 3.06^{\mathrm{b}}$ & $69.00 \pm 2.14^{\mathrm{b}}$ & $66.60 \pm 2.34^{\mathrm{b}}$ & $67.0 \pm 0.83^{\mathrm{b}}$ & $68.20 \pm 0.37^{b}$ & $70.0 \pm 0.70^{\mathrm{b}}$ \\
\hline $\mathrm{N}+$ Ethanol & $83.00 \pm 2.30^{\mathrm{a}}$ & $81.0 \pm 1.92^{\mathrm{a}}$ & $71.20 \pm 2.52^{\mathrm{b}}$ & $66.00 \pm 2.21^{\mathrm{b}}$ & $68.00 \pm 1.82^{\mathrm{b}}$ & $69.4 \pm 1.20^{\mathrm{b}}$ & $69.0 \pm 0.44^{\mathrm{b}}$ & $70.8 \pm 0.96^{b}$ \\
\hline D/Control & $399.4 \pm 19.08^{b}$ & $401.4 \pm 18.32^{\mathrm{b}}$ & $449.4 \pm 24.69^{c}$ & $437.0 \pm 17.37^{\mathrm{d}}$ & $427.2 \pm 9.99^{\mathrm{d}}$ & $437.4 \pm 10.45^{\mathrm{e}}$ & $424.8 \pm 9.11^{\mathrm{e}}$ & $417.0 \pm 9.82^{\mathrm{e}}$ \\
\hline D+Aqueous & $420.6 \pm 23.83^{b}$ & $418.6 \pm 22.89^{\mathrm{b}}$ & $404.60 \pm 25.06^{c}$ & $353.2 \pm 9.26^{\mathrm{c}}$ & $315.40 \pm 15.65^{\mathrm{c}}$ & $279.0 \pm 14.07^{c}$ & $192.2 \pm 13.05^{\mathrm{c}}$ & $143.0 \pm 5.35^{\mathrm{c}}$ \\
\hline D+Ethanol & $442.2 \pm 26.93^{b}$ & $439.4 \pm 26.04^{b}$ & $423.40 \pm 20.42^{\mathrm{c}}$ & $342.0 \pm 10.89^{c}$ & $297.80 \pm 15.65^{\mathrm{c}}$ & $237.4 \pm 7.43^{\mathrm{d}}$ & $150.6 \pm 8.10^{\mathrm{d}}$ & $121.2 \pm 4.88^{\mathrm{d}}$ \\
\hline
\end{tabular}

TABLE 4: Lipid profile of normal and streptozotocin induced diabetic rats treated with $250 \mathrm{mg} / \mathrm{kg}$ bw of aqueous and ethanol extracts of Strophanthu shispidus stem bark for 12 weeks

\begin{tabular}{lllll}
\hline \multicolumn{5}{c}{ Strophanthu shispidus stem bark for 12 weeks } \\
\hline Treatment & Total Chol. & TG & HDL & LDL \\
\hline N/Control & $128.0 \pm 0.84^{\mathrm{b}}$ & $113.6 \pm 1.44^{\mathrm{c}}$ & $25.0 \pm 0.94^{\mathrm{c}}$ & $87.8 \pm 1.46^{\mathrm{b}}$ \\
N+Aqueous & $120.0 \pm 0.70^{\mathrm{a}}$ & $75.8 \pm 2.96^{\mathrm{a}}$ & $26.2 \pm 1.46^{\mathrm{c}}$ & $70.8 \pm 1.77^{\mathrm{a}}$ \\
N+Ethanol & $118.4 \pm 1.03^{\mathrm{a}}$ & $99.6 \pm 3.83^{\mathrm{b}}$ & $24.6 \pm 1.63^{\mathrm{bc}}$ & $73.6 \pm 1.96^{\mathrm{a}}$ \\
D/Control & $178.2 \pm 3.34^{\mathrm{d}}$ & $144.6 \pm 2.02^{\mathrm{d}}$ & $10.4 \pm 0.50^{\mathrm{a}}$ & $137.6 \pm 3.52^{\mathrm{c}}$ \\
D+Aqueous & $135.2 \pm 1.83^{\mathrm{c}}$ & $120.8 \pm 1.24^{\mathrm{c}}$ & $17.6 \pm 0.50^{\mathrm{d}}$ & $93.2 \pm 1.91^{\mathrm{b}}$ \\
D+Ethanol & $130.8 \pm 2.01^{\mathrm{bc}}$ & $94.0 \pm 3.52^{\mathrm{b}}$ & $21.4 \pm 1.28^{\mathrm{b}}$ & $90.4 \pm 1.28^{\mathrm{b}}$ \\
\hline
\end{tabular}

Values are concentrations of serum lipids in $\mathrm{mg} /$ dl and are means \pm SEM $(n=5)$. Values in the same column with different superscript alphabet are significant $(P<0.05)$ from controls $(N \& D)$. (N=normal, $D=$ diabetic; $N /$ Control= normal control, D/control=diabetic control, Chol=cholesterol, $T G=$ triglyceride, $H D L=$ high density lipoprotein, $L D L=$ low density lipoprotein).

TABLE 5: Mean serum amylase activity in normal and streptozotocin induced diabetic rats treated with $250 \mathrm{mg} / \mathrm{kg}$ bw of aqueous and ethanol extracts of Strophanthushispidusstem bark for 12 weeks

\begin{tabular}{l|l}
\hline Treatment & Amylase activity (IU/L) \\
\hline N/Control & $414.0 \pm 14.78^{\mathrm{d}}$ \\
N+Aqueous & $427.4 \pm 2.63^{\text {cd }}$ \\
N+Ethanol & $459.6 \pm 10.90^{\mathrm{c}}$ \\
D/Control & $228.8 \pm 5.92^{\mathrm{a}}$ \\
D+Aqueous & $352.8 \pm 13.18^{\mathrm{b}}$ \\
D+Ethanol & $370.2 \pm 15.66^{\mathrm{b}}$
\end{tabular}

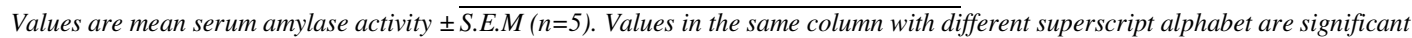
$(P<0.05)$ from controls $(N \& D) .(N=$ normal, $D=$ diabetic; $N /$ Control= normal control, $D /$ control=diabetic control

Fasting Blood Glucose Concentration:Diabetes Mellitus (DM) is a common disorder associated with increased morbidity and mortality and can be defined as a group of metabolic diseases characterized by chronic hyperglycemia due to defective insulin secretion, insulin action, or both, resulting in impaired 
carbohydrate, lipid, and protein metabolism (Akahet al. 2009). Diabetes tends to damage cell membranes which results in elevated production of reactive oxygen species (ROS).The generation of ROS appears to play a critical role in the pathogenesis of diabetes mellitus (Harnett et al. 2000).

TABLE 6:Body weight of normal and streptozotocin induced diabetic rats treated with $250 \mathrm{mg} / \mathrm{kg}$ bw of aqueous and ethanol extracts of Strophanthushispidusstem bark for 12 weeks

\begin{tabular}{llllclll}
\hline \multicolumn{7}{c}{ Weight of animals $(\mathrm{g})$} \\
\hline Treatment & Basal & Week 2 & Week 4 & Week 6 & Week 8 & Week 10 \\
\hline N/Control & $255.8 \pm 8.26^{\mathrm{a}}$ & $268.6 \pm 7.78^{\mathrm{ab}}$ & $287.8 \pm 9.67^{\mathrm{b}}$ & $320.6 \pm 8.90^{\mathrm{c}}$ & $347.0 \pm 8.46^{\mathrm{cd}}$ & $335.6 \pm 3.14^{\mathrm{d}}$ & $346.4 \pm 6.12^{\mathrm{d}}$ \\
N+Aqueous & $277.4 \pm 4.23^{\mathrm{a}}$ & $294.8 \pm 9.39^{\mathrm{ab}}$ & $323.2 \pm 9.72^{\mathrm{bc}}$ & $321.8 \pm 14.39^{\mathrm{bc}}$ & $339.2 \pm 16.15^{\mathrm{c}}$ & $331.4 \pm 18.37^{\mathrm{bc}}$ & $342.0 \pm 15.37^{\mathrm{c}}$ \\
N+Ethanol & $275.2 \pm 3.62^{\mathrm{a}}$ & $299.6 \pm 9.09^{\mathrm{ab}}$ & $297.8 \pm 8.68^{\mathrm{ab}}$ & $318.0 \pm 14.07^{\mathrm{b}}$ & $332.0 \pm 14.13^{\mathrm{b}}$ & $319.0 \pm 15.87^{\mathrm{b}}$ & $298.2 \pm 15.57^{\mathrm{ab}}$ \\
D+Control & $255.8 \pm 1.46^{\mathrm{a}}$ & $238.4 \pm 2.01^{\mathrm{b}}$ & $235.6 \pm 1.72^{\mathrm{b}}$ & $216.8 \pm 5.25^{\mathrm{c}}$ & $200.6 \pm 4.57^{\mathrm{d}}$ & $190.4 \pm 3.92^{\mathrm{d}}$ & $180.0 \pm 4.01^{\mathrm{e}}$ \\
D+Aqueous & $220.4 \pm 6.26^{\mathrm{a}}$ & $236.0 \pm 8.15^{\mathrm{ab}}$ & $238.8 \pm 6.06^{\mathrm{ab}}$ & $247.8 \pm 8.49^{\mathrm{bc}}$ & $269.6 \pm 9.15^{\mathrm{c}}$ & $268.4 \pm 9.46^{\mathrm{c}}$ & $264.4 \pm 10.78^{\mathrm{c}}$ \\
D+Ethanol & $232.8 \pm 9.29^{\mathrm{a}}$ & $237.0 \pm 8.83^{\mathrm{ab}}$ & $239.8 \pm 6.89^{\mathrm{ab}}$ & $254.4 \pm 5.26^{\mathrm{bc}}$ & $273.4 \pm 6.41^{\mathrm{c}}$ & $263.8 \pm 6.20^{\mathrm{c}}$ & $259.0 \pm 4.62^{\mathrm{bc}}$ \\
\hline
\end{tabular}

Values are means weight of animals in grams \pm S.E.M $(n=5)$. Values in the same row with different superscript alphabet are significantly $(\mathrm{P}<0.05)$ different from basal value.

Hyperglycemia associated with diabetes also increases the production of ROS and affects antioxidant enzymes and reactions (Uchimuraet al., 1999; Kowluruet al. 2000; Haskins et al. 2004). The diagnosis of diabetes mellitus depends solely on the demonstration of hyperglycemia. For type 1 diabetes, the diagnosis is usually easy because hyperglycemia (1) appears abruptly, (2) is severe, and (3) is accompanied by serious metabolic derangements. Diagnosis of type 2 diabetes may be difficult because the metabolic changes are often not severe enough for the patient to notice symptoms of them (Tietz 2008). In spite of the presence of known antidiabetic medicines in the pharmaceutical market, therapies from herbal medicines are used with success for the management of diabetes (Bhattaramet al. 2002). The antidiabetic effects of these plants is due to their capability to restore the function of pancreatic $\beta$-cells by causing a rise in insulin production or by inhibiting the intestinal absorption of glucose or by the facilitation of metabolites in insulin dependent processes (Elder 2004; Fatima et al, 2010). In this study, significant $(\mathrm{P}<0.05)$ progressive decrease in fasting blood glucose concentrations of both normal and diabetic rats treated with the extracts were observed when compared with the respective controls (normal and diabetic control). Significant reduction in fasting blood glucose were observed for the normal rats treated with the extracts from the $2^{\text {nd }}-12^{\text {th }}$ weeks whereas the diabetic treated rats showed significant blood glucose reduction from the $4^{\text {th }}-12^{\text {th }}$ weeks of administration. However, no significant effect was observed in the normal control rats when compared with its basal value, whereas the diabetic control rats had significant increase. The result is as presented in Table III. The reduction in fasting blood glucose observed in this study may be attributed to the presence of bioactive compound in the plant (Osibemhe\&Onoagbe 2015). It is also possible that SH exerts its hypoglycemic and anti-diabetic potential through one of the mechanism postulated by Elder (2004); Fatima et al. (2010).Another possible mechanism by which SH might exert its hypoglycemic effect may be by buttressing the body's antioxidant system. Phytochemicals such as flavonoids and tannins are known to scavenge free radicals (Berengueret al. 2006) and build up immunity respectively, thus taking care of the stimulation of free radicals and oxidative stress as a result of high glucose levels.

Body Weight:The mechanisms by which streptozotocin brings about its diabetic state include selective destruction of pancreatic insulin secreting $\beta$ cells, which make cells less active and lead to poor glucose utilization by tissues (Lenzen 2008). In this study, progressive increases in weight of normal and diabetic rats treated with the extracts were observed on the $2^{\text {nd }}-12^{\text {th }}$ weeks of administration when compared with the basal values whereas the diabetic control rats had progressive decrease in weight. The result is as presented in Table VI. The observed decrease in weight in diabetic control rats in this study might be as a result of STZ's activity on the pancreatic beta cells. Since the body cells will persistently require glucose, fats and proteins are mobilized to produce glucose and hence energy. This accounts for the depletion of energy stores and weight loss due to loss of tissue proteins and muscle mass in type 1 diabetes (Mishra et al. 2012). It is known that glycosuria causes a significant loss of calories for every gram of glucose excreted and most likely, this loss results in severe weight loss in spite of increased appetite, particularly when it is coupled with loss of muscle and adipose tissue due to excessive break down of protein (Akpasoet al. 2011). The observed increase in weight for the diabetic treated rats in this study may be that $\mathrm{SH}$ has repaired the damage caused by STZ on the pancreas. 
Lipid Profile:Hypertriacylglycerolemia and hypercholesterolemia, are common occurrences of chronic uncontrolled diabetes and usually contribute to the pathogenesis of vascular complications in diabetes (Scoppolaet al. 2001; Meyes 2003). Dyslipidemia (apparent alterations in the level of serum lipid, triglycerides and lipoprotein levels) implicated in diabetes mellitus (Maghraniet al. 2004) is mainly due to the increase in the mobilization of free fatty acids from the peripheral depots (adipose tissue) to the blood (Shukla et al. 2003), since insulin is known to inhibit the hormone sensitive lipase (Daisy \&Feril 2013). In this study, the concentrations of total cholesterol, TG, and LDL-cholesterol of diabetic rats were significantly $(\mathrm{P}<0.05)$ lowered by extracts of $\mathrm{SH}$, whereas it increased the concentration of HDL-cholesterol when compared with diabetic control. Total cholesterol, TG and LDL-cholesterol concentrations in normal rats also had significant $(\mathrm{P}<0.05)$ reduction when compared with normal control, whereas $\mathrm{SH}$ had no significant effect $(\mathrm{P}>0.05)$ on HDL-cholesterol concentration of normal rats. The result is as presented in Table IV.The reduction of the increased total cholesterol, LDL-C, triglycerides in diabetic rats by $\mathrm{SH}$ and the concomitant increase in HDL-C may be beneficial in preventing diabetic complications and improving lipid metabolism in diabetics (Cho et al. 2002). Lowering of lipid levels in rats by plant extracts have been reported to be due to antioxidant activity of phytochemical compounds such as flavonoids (Igarasi\&Ohmuma 1995). Osibemhe and Onoagbe (2015) have reported the presence of flavonoids in SH. The observed reduction in total or LDL-cholesterol in normal rats by extracts of $\mathrm{SH}$ may be attributed to the effect of saponins. Saponins are known antinutritional factors which reduce the uptake of certain nutrient especially cholesterol at the gut through intraluminal physiochemical interactions. Hence, saponins have been reported to have hypocholesterolic effect (Price et al. 1987). The presence of saponins in $\mathrm{SH}$ has been reported (Osibemhe and Onoagbe 2015). These results are in agreement with the results of Owolabiet al. (2010) in normal rats treated with Blighiasapida extracts. Other possible mechanisms by which plants extracts could reduce lipid profile have been reported (Owolabiet al.2010; Ghada 2013).

Amylase Activity:Pancreas is a doubled-entity organ, with both an exocrine and an endocrine component, reciprocally interacting and closely cooperating for the digestion, absorption, and metabolism of oral nutrients (Pieler\& Chen 2006). It is well documented, that intact islets of Langerhans is necessary for the normal pancreatic exocrine function (Moessneret al. 1985). Moreover, the exocrine pancreas is influenced by the islet hormones not only systemically but also through a direct islet-acinar portal system (Iwabe et al. 2001). It is well documented that both pancreatic secretory processes and pancreatic growth are (at least partially) under the control of islet hormones. In patients with diabetes mellitus (DM), several reports have documented gross and microscopic alterations of the morphology of acinar cells, some showing pancreatic duct changes recalling a chronic pancreatitis (Silva et al. 1993; Nakanishi et al. 1994; Hardtet al. 2002; Bilginet al. 2009). The impaired exocrine pancreatic function in diabetic patients may be a result of multiple factors, the most important being glucagon inhibiting influence and lack of insulin stimulation on synthesis in exocrine cells (Hardtet al. 2000; Harding et al. 2001). Lack or attenuation of neurovegetative stimulation following diabetic neuropathy also leads to decreased enzyme secretion (Boiadzhieva 1990). In this study, extract of $\mathrm{SH}$ had significant $(\mathrm{P}<0.05)$ increases in the activity of amylase in normal and diabetic treated rats when compared with their respective controls, with the exception of aqueous extract which had a non-significant increase in normal rats as presented in Table $\mathrm{V}$. The decrease in the activity of $\alpha$-amylase observed in this study in diabetic control relative to normal control may be ascribe to lack of insulin stimulation on synthesis in exocrine cells(Hardtet al. 2000; Harding et al. 2001) since STZ affects the $\beta$-cells of the pancreas that are responsible for the production or release of insulin. The increase in the activity of $\alpha$-amylase in diabetic treated rats relative to diabetic control may be that the extracts were able to repair the damage by STZ on pancreatic $\beta$-cells which in turns improved insulin production and secretion. Saito et al. (1980) have reported that both endogenous and exogenous insulin evoke an increase in pancreatic growth and enzyme synthesis. The direct (via acinar insulin receptors) and indirect (influence on cholecystokinin (CCK) mechanism) effects of insulin on protein synthesis and secretion is well documented. Burskiet al. (2004) have reported decrease in $\alpha$ amylase activity in their study on serum amylase activity disorders in the course of experimental diabetes in rabbits. Choosing serum $\alpha$-amylase as an indicator of the exocrine pancreatic function is based on the enzyme's relative stability, long breakdown period, high sensitivity and specificity, in comparison with other pancreatic enzymes being also used in daily clinical practice (Burskiet al. 2004).

Conclusion:It suffices to say from the results that 250 $\mathrm{mg} / \mathrm{kg}$ of $\mathrm{S}$. hispidus possesses hypoglycemic, antihyperlipidemic and anti-diabetic activities. These findings have given credence to the use of $S$. hispidus for the management of diabetes by the indigenous people of Africa. However, further study is recommended in order to isolate and characterize the 
active compound in this plant and subject it to experimental and clinical trial to further validate its potency in diabetes management.

\section{REFERENCES}

Akah, JA;Lemji, JA;Salawa, OA;Okoye, TC; Offiah, NV(2009). Effects of Vernoniaamygdalina on Biochemical and Haematological Parameters in Diabetic Rats. Asian J. Med. Sci, 1(3): 108-113.

Akpaso, MI;Atangwho, IJ;Akpantah, A; Fischer, VA;Igiri, AO; Ebong, PI (2011). Effect of combined leaf extracts of Vernoniaamygdalina (Bitter leaf) and Gongronemalatifolium(Utazi) on the pancreatic $\beta$-cells of streptozotocin-induced diabetic rats. $\mathrm{Br} J$ Med Res, 1:24-34.

Berenguer,B; Sanchez, LM;Quilez, A; Lopez, MB;Haro, OD; Galvez, J; Martin, MJ(2006). Protective and antioxidant effects of Rhizophora mangle L. against NSAID induced gastric ulcers. J. Ethnopharmacol., 103:194.

Bhattaram, VA;Graefe, U;Kohlest, C;Veit, M;Deundorf, $\mathrm{H}(2002)$. Pharmacokinetics and bioavailability of herbal medicinal products. Phytomedicine,9(3): 133.

Bilgin, M;Balci, NC;Momtahen, AJ;Bilgin, Y; Klör, HU (2009). MRI and MRCP findings of the pancreas in patients with diabetes mellitus: compared analysis with pancreatic exocrine function determined by fecalelastase 1. J ClinGastroenterol, 43: 165-170.

Boiadzhieva, N. (1990). The effect of dopaminergic pharmacological agents on the pancreatic islet apparatus in rats. Eksp. Med. Morfol, 29: 20-26.

Burski, K;Ueland, T;Maciejewski, R(2004). Serum amylase activity disorders in the course of experimental diabetes in rabbits Vet Med Czech, 49(6): 197-200.

Cho, SY; Park, JY; Park, EM; Choi, MS; Lee, MY; Jeon, SM; Jang, MK; Kim, M J; Park, YB(2002). Alternation of hepatic antioxidant enzyme activities and lipid profile in streptozotocin-induced diabetic rats by supplementation of dandelion water extract. Clin. Chim. Acta, 317: 109 - 117.

Daisy, P;Feril, GJK (2013). Hypolipideamic and hepatoprotective effect of Cassia auriculataLinn bark extracts on streptozotocin induced diabetics in male Wistar albino rats. Asian J. Pharmaceut. Clin. Res, 6(2): 43-48.
Elder, C(2004). Ayurveda for diabetes mellitus: A review of the biomedical literature. Altern. Ther Health Med, 10(1): 44-50.

Fatima, SS;Rajasekhar, MD; Kumar,KV; Kumar, MTS;Babu, KR; Rao, CA(2010). Antidiabetic and antihyperlipidemic activity of ethyl acetate: Isopropanol (1:1) fraction of Vernoniaanthelminticaseeds in Streptozotocin induced diabetic rats. Food ChemToxicol, 48(2): 495-501.

Ghada, ZAS. (2013). "Effect of RosmarinusOfficinalison Lipid Profile of Streptozotocin-Induced Diabetic Rats", J Res Diabetes, 2013: 1-9.

Gupta, C. (2000). Reproductive malformation of the male offspring following maternal exposure to estrogenic chemicals. Proceedings of the Society for Experimental Biology and Medicine, 224, 61-68.

Harding, HP; Zeng, H; Zhang, Y;Jungries, R; Chung, P;Plesken, H; Sabatini, DD; Ron, D. (2001). Diabetes mellitus and exocrine pancreatic dysfunction in perk-/- mice reveals a role for translational control in secretory cell survival. $\mathrm{Mol}$. Cell., 7: 1153-1163.

Hardt, PD;Killinger, A;Nalop, J; Schnell-Kretschmer, H; Zekorn, T. (2002). Chronic pancreatitis and diabetes mellitus. A retrospective analysis of 156 ERCP investigations in patients with insulin-dependent and non-insulin-dependent diabetes mellitus. Pancreatology, 2: 30-33.

Hardt, PD; Krauss, A;Bretz, L;Porsch-Ozcurumez, M; Schnell-Kretschmer, H; Maser, E;Bretzel, RG;Zekhorn, T;Klor, HU (2000). Pancreatic exocrine function in patients with type 1 and type 2 diabetes mellitus. ActaDiabetol.,37: 105-110.

Harnett, EM; Stratton, RD; Browne, RW;Rosner, BA;Lanharm, R J; Armstrong, D. (2000). Serum markers of oxidative stress and severity of diabetic retinopathy. Diabetes Care, 23: 234-240.

Haskins, K;Kench, J; Powers, K; Bradley, B;Pugazhenthi, S;Reusch, J; McDuffie, M. (2004). Role of Oxidative stress in the regeneration of Islet beta cells? J. Investig. Med, 52: 45 - 49 .

Igarasi, K; Ohmuma, M. (1995). Effect of rhamnetin and quercetin on concentration of cholesterol and lipoperoxidase in the serum and liver and the blood and liver antioxidative enzyme activities of rats. Biosci. Biotechnol. Biochem, 59: 595-601. 
Iwabe, C;Shiratori,K; Shimizu, K; Hayashi, N. (2001). Role of endogenous insulin in pancreatic secretion in rats. Pancreatology, 1(4):300-305.

Kowluru, RA;Engerman, RL; Kern, TS. (2000). Diabetes induced metabolic abnormalities in kyocardium: Effect of antioxidant therapy. Free Radic. Res, 32: 67-74.

Lenzen, S.(2008). The mechanisms of action of alloxanand Streptozotocininduced diabetes. Diabetologia, 51: 216- 226.

Maghrani, M;Lemhadri, A;Zeggwagh, NA; El Amraoui, M;Haloui, M;Jouad, H;Eddouks M. (2004). Effects of an aqueous extract of Triticumrepens on lipid metabolism in normal and recent-onset diabetic rats. J. Ethnopharmacol., 90(2-3): 331-337.

Meyes, PA. (2003). Lipid transport and storage; in Harper's Biochemistry $25^{\text {th }}$ ed., McGraw-Hill, New York, pp. 268-284.

Mishra, B;Pancholi, SS;Deshmukh, AB;Panjwani, D. (2012). Preclinical investigation of a novel dose Regimen based on the combination of pioglitazone and Gymnemasylvestre extract. MolClinPharmacol, 2: $20-30$.

Moessner, J; Logsdon, CD; Williams, JA; Goldfine, ID. (1985). Insulin, via its own receptor, regulates growth and amylase synthesis in pancreatic acinar AR42J cells. Diabetes, 34: 891-897.

Nakanishi, K; Kobayashi, T; Miyashita, H; Okubo, M; Sugimoto, T. (1994). Exocrine pancreatic ductograms in insulin-dependent diabetes mellitus. Am J Gastroenterol, 89: 762-766.

National Institute of Health (1992). Institutional Animal Care and use Committee Guidebook, NIH Publication. U.S. Government Printing Office, Washington, D. C., 92-345.

Osibemhe, M;Onoagbe, IO (2015). Qualitative and quantitative phytochemical evaluations of Strophanthushispidusstem bark. IOSR J Pharm BiolSci, 10(2):124-128.

Owolabi, OA; James, DB; Ibrahim, AB;Folorunsho, OF;Bwalla, I; Akanta, F. (2010). Changes in Lipid Profile of Aqueous and Ethanolic Extract of Blighiasapida in Rats. Asian Journal of Medical Sciences 2(4):177-180.

Pieler, T; Chen, Y. (2006). "Forgotten and noval aspects in pancreas development," Biology of the Cell, 98(2): 79-88.
Price, KR; Johnson, LI; Feriwick, H. (1987). The chemical and biological significance of saponins in foods and feeding stuffs. CRC Critical Revigar. Food Sci. Nutr, 26: 127-135.

Saito, A; Williams, JA; Kanno, T. (1980). Potentiation of cholecystokinin-induced exocrine secretion by both exogenous and endogenous insulin in isolated and perfused rat pancreata. J Clin Invest, 65: 777-782.

Scoppola, A;Montechi, FR;Mezinger, G;Lala, A. (2001). Urinary mevalonate excretion of rats in type 2 diabetes: role of metabolic control. Atherosclorosis, 156: $357-361$

Shukla, N;Angelini, GD; Jeremy, JY. (2003). Homocysteine as a risk factor for nephropathy andretinopathy in type 2 diabetes.Diabetologia, 46: 766-772.

Silva, ME;Vezozzo, DP;Ursich, M J; Rocha, DM; Cerri, GG. (1993). Ultrasonographic abnormalities of the pancreas in IDDM and NIDDM patients. Diabetes Care, 16: 1296-1297.

Tapas, A;Sakarkar, D;Kakde, R. (2008). Flavonoid as Nutraceuticals: A Review. Trop J Pharm Res, 7: 1089-1099.

Tietz, NW. (2008).CarbohydratesIn: Tietz Fundamentals of Clinical Chemistry. Burtis CA, Ashwood ER, and Bruns DE (ed.) 6th ed. W. B. Saunders Company, London, p. 380.

Uchimura, K;Nagasaka, A;Hayashi, R;Makino, M;Nagata, M;Kakizawa, H; Kobayashi, T;Fujiwara, K;Kato, T;Iwase, K;Kato, K;Itoh, M. (1999). Changes in superoxidedismutaseactivities and concentrations and myoloperoxidaseactivities in leucocytesfrompatientswith diabetes mellitus. $J$. Diab. Comp, 13: 264-270.

Von, SF;Timms, BG; Montano, MM;Palanza, P; Thayer, KA;Nagel, SC;Dhar, MD;Ganjam, VK;Parmigiani, S; Welshons, WV. (1997). Prostateenlargement in micedueto fetal exposuretolow doses of extradiolordiethylstilbestrol and oppositeeffects at high doses. ProcNatlAcadSci, 94, 2056-2061.

World Health Organisation(2016). Global report on diabetes. 